\title{
Simultaneous multicopter-based air sampling and sensing of meteorological variables
}

\author{
Caroline Brosy $^{1}$, Karina Krampf ${ }^{1}$, Matthias Zeeman ${ }^{1}$, Benjamin Wolf ${ }^{1}$, Wolfgang Junkermann ${ }^{1}$, Klaus Schäfer ${ }^{1}$, \\ Stefan Emeis ${ }^{1}$, and Harald Kunstmann ${ }^{1,2}$ \\ ${ }^{1}$ Institute of Meteorology and Climate Research (IMK-IFU), Karlsruhe Institute of Technology, \\ 82467 Garmisch-Partenkirchen, Germany \\ ${ }^{2}$ Institute of Geography, University of Augsburg, 86159 Augsburg, Germany \\ Correspondence to: Caroline Brosy (caroline.brosy@kit.edu)
}

Received: 6 March 2017 - Discussion started: 20 March 2017

Revised: 21 June 2017 - Accepted: 6 July 2017 - Published: 1 August 2017

\begin{abstract}
The state and composition of the lowest part of the planetary boundary layer (PBL), i.e., the atmospheric surface layer (SL), reflects the interactions of external forcing, land surface, vegetation, human influence and the atmosphere. Vertical profiles of atmospheric variables in the $\mathrm{SL}$ at high spatial (meters) and temporal $(1 \mathrm{~Hz}$ and better) resolution increase our understanding of these interactions but are still challenging to measure appropriately. Traditional ground-based observations include towers that often cover only a few measurement heights at a fixed location. At the same time, most remote sensing techniques and aircraft measurements have limitations to achieve sufficient detail close to the ground (up to $50 \mathrm{~m}$ ). Vertical and horizontal transects of the PBL can be complemented by unmanned aerial vehicles (UAV). Our aim in this case study is to assess the use of a multicopter-type UAV for the spatial sampling of air and simultaneously the sensing of meteorological variables for the study of the surface exchange processes. To this end, a UAV was equipped with onboard air temperature and humidity sensors, while wind conditions were determined from the UAV's flight control sensors. Further, the UAV was used to systematically change the location of a sample inlet connected to a sample tube, allowing the observation of methane abundance using a ground-based analyzer. Vertical methane gradients of about $0.3 \mathrm{ppm}$ were found during stable atmospheric conditions. Our results showed that both methane and meteorological conditions were in agreement with other observations at the site during the ScaleX-2015 campaign. The multicopter-type UAV was capable of simultaneous in situ sensing of meteorological state variables and sampling of air
\end{abstract}

up to $50 \mathrm{~m}$ above the surface, which extended the vertical profile height of existing tower-based infrastructure by a factor of 5 .

\section{Introduction}

The planetary boundary layer (PBL) is the lowest part of the atmosphere directly influenced by the Earth's surface and reflects interactions between land surface, vegetation, human activities and the atmosphere (Stull, 1988). Since mixing processes and transport or the lack thereof affect trace gas and aerosol distributions in the atmosphere on all scales, vertical profiles provide more detailed information, which have to be accounted for when dealing with emission and flux estimations (Worden et al., 2012).

Well-known in situ platforms for the measurement of vertical profiles of atmospheric variables in the PBL are towers, (tethered) balloons and radiosondes (Konrad et al., 1970). The operation of towers is fixed to a certain location and the vertical information is limited to the height of the tower as well as to discrete levels at the tower. However, towers provide continuous recording of the investigated variables and are routinely used (e.g., Sasakawa et al., 2010; Wang et al., 2013; Andrews et al., 2014). With radiosondes, balloons or kites, information of meteorological conditions can be acquired for an extended vertical range, but these systems are expensive and the location of the vertical profiles is dependent on atmospheric conditions. Nevertheless, mobile and temporary applications are possible. Research aircraft and 
satellites cover large areas in the range of kilometers within a short time span, but their operation close to the ground is still challenging (Velasco et al., 2008; Martin et al., 2011). Considering ground-based remote sensing methods, data of vertical profiles from low altitudes up to about $50 \mathrm{~m}$ above ground level (a.g.l.) are hardly usable (e.g., acoustic instruments) but are possible with lidars applying certain scan patterns with low elevation angles at the position of such an instrument (Emeis et al., 2009; Banta et al., 2013; Korhonen et al., 2014; Hammann et al., 2015).

From the 1970s on, unmanned aerial vehicles (UAVs) were used for atmospheric research, for example for convective processes (Konrad et al., 1970; Rennó and Williams, 1995) and weather forecasting (Holland et al., 1992; McGeer and Holland, 1993) as well as for vertical sounding of the PBL (Egger et al., 2002; Soddell et al., 2004; Spiess et al., 2007). In recent years, UAVs have become increasingly used as flying platforms for measurements in atmospheric research for both vertical and horizontal applications (Villa et al., 2016). Martin et al. (2011) demonstrated the utilization of fixed-wing UAVs for measurements of meteorological variables, i.e., air temperature, humidity and wind, up to $1600 \mathrm{~m}$ above ground level (a.g.l.). In addition, de Boer et al. (2016) implemented radiation and aerosol size distributions sensors, Altstädter et al. (2015) focused on ultrafine particles and Båserud et al. (2016) showed the possibility of turbulence measurements. Nathan et al. (2015) measured methane with an in situ sensor flying around a compressor station to calculate its emissions. The importance of knowing both meteorological conditions and methane (or aerosols, particulate matter, etc.) has been highlighted in previous studies (e.g., Bamberger et al., 2014; Mathieu et al., 2005). Fixedwing systems can cover a vertical and horizontal range of several kilometers and therefore are suitable for investigations throughout the boundary layer. Multicopters offer flexible maneuverability at low flight speed and the possibility of hovering (i.e., no horizontal movement). Their applications include meteorological and air quality measurements, e.g., particulate matter (Alvarado et al., 2015) or air samples for analyses of chemical composition (Chang et al., 2016), but on a smaller scale of several hundreds of meters. In addition, Neumann and Bartholomai (2015) and Palomaki et al. (2017) showed that the onboard flight control sensors can be used to derive wind estimates from a multicopter's attitude control data. Although small and lightweight methane sensors are available (Berman et al., 2012; Khan et al., 2012), current model multicopters with a takeoff weight below $5 \mathrm{~kg}$ still require further miniaturization of the sensors. As a consequence, mobile investigations of vertically resolved profiles of greenhouse gases in combination with information about atmospheric state variables are not conventionally applied yet.

Methane $\left(\mathrm{CH}_{4}\right)$ is the second-most-important greenhouse gas with regard to global warming and has a global warming potential 20 times that of carbon dioxide (Forster et al.,
2007). Its current concentration is more than twice as much as before preindustrial times (Kirschke et al., 2013; Saunois et al., 2016). While the global budget is well known, this is not the case for regional to local scales, especially vertical distributions (Dlugokencky et al., 2011). Using tethered balloons, Choularton et al. (1995), Beswick et al. (1998) and Stieger et al. (2015) investigated the vertical methane distribution within the nocturnal boundary layer (NBL) by pulling up a sampling tube.

In this case study we aim to assess the feasibility of a multicopter-type UAV approach to detach methane and meteorological measurements at a tower by pulling up a tube with a multicopter weighing below $5 \mathrm{~kg}$. Both methane and atmospheric state are important to analyze the vertical methane distribution focusing on stable atmospheric conditions above a typical agricultural setting in the foothills of the Bavarian Alps. The nighttime is of particular interest because turbulent mixing is low and vertical methane gradients can develop.

\section{Methodology}

\subsection{Site description and instrumentation}

The first experiments with our multicopter took place at the measurement site Fendt (DE-Fen) of the TERENOpreAlpine (TERrestrial ENvironmental Observatory) observatory (Zacharias et al., 2011) during the ScaleX campaign (Wolf et al., 2017) in June and July 2015. This intensive campaign aimed to address atmosphere-land surface interactions across different scales with both measurements and modeling. As a long-term TERENO site, DE-Fen has already been equipped with automated instrumentation and continuous data availability for several years. During ScaleX, measurements of energy, water and greenhouse gas fluxes were extended in time and spatial resolution to investigate spatial patterns and vertical gradients to obtain three-dimensional and more detailed information.

DE-Fen $\left(47.832^{\circ} \mathrm{N}, 11.062^{\circ} \mathrm{E} ; 600 \mathrm{~m}\right.$ above sea level, a.s.l.) is located in a north-south-oriented valley in the foothills of the Bavarian Alps in southern Germany (Fig. 1). While the surface is relatively flat towards the east, about $300 \mathrm{~m}$ to the west a steep forested slope of about 100 to $130 \mathrm{~m}$ borders the grassland in the valley. Thus, orographical winds and diurnal wind systems favor northerly and southerly directions with occasional easterly or northeasterly components. Westerly winds are normally associated with orographic turbulence. Prevailing land use is grassland with sporadic croplands. Further details on climate characteristics of the region can be found in Kunstmann et al. (2004, 2006).

The site is equipped with, among other instruments, a permanent eddy-covariance (EC) station for carbon dioxide, water vapor and energy flux measurements (Mauder et al., 2013; Zeeman et al., 2017). An overview about the location of instruments is given in Fig. 1. During the campaign, a ra- 


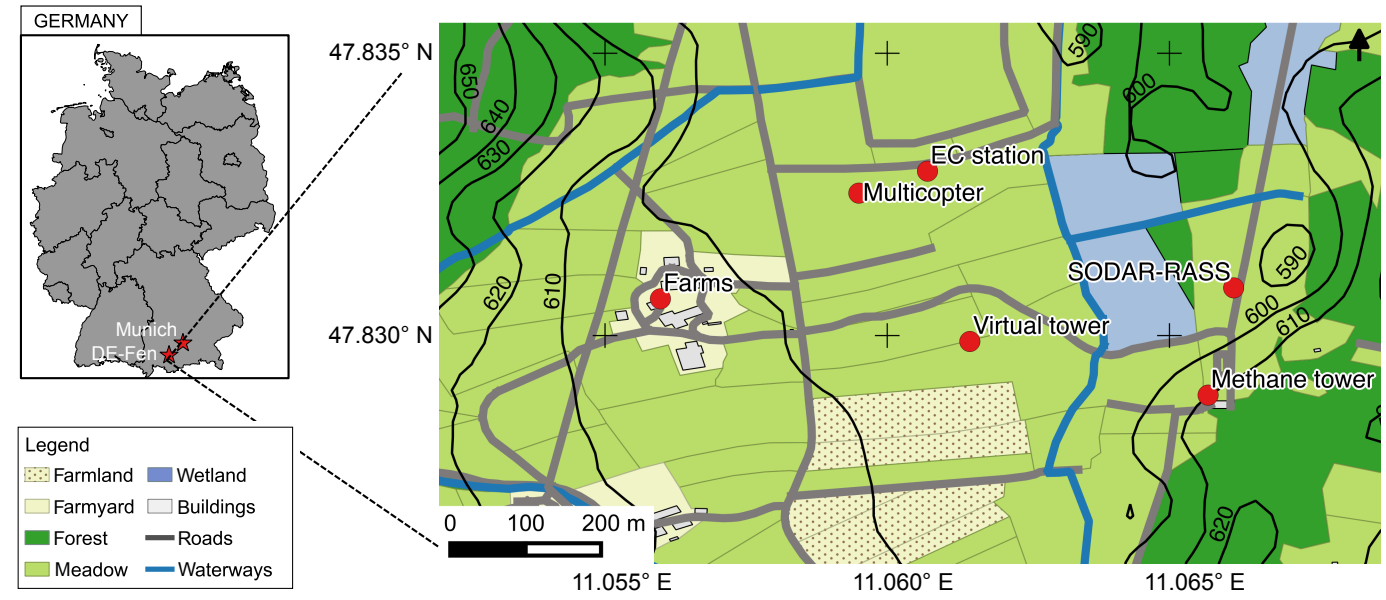

Figure 1. Measurement site DE-Fen, Germany, with land use and ground-based instrumentation important for this study during the ScaleX2015 campaign. Contour lines stand for altitude (m) above sea level (QGIS, OpenStreetMap).

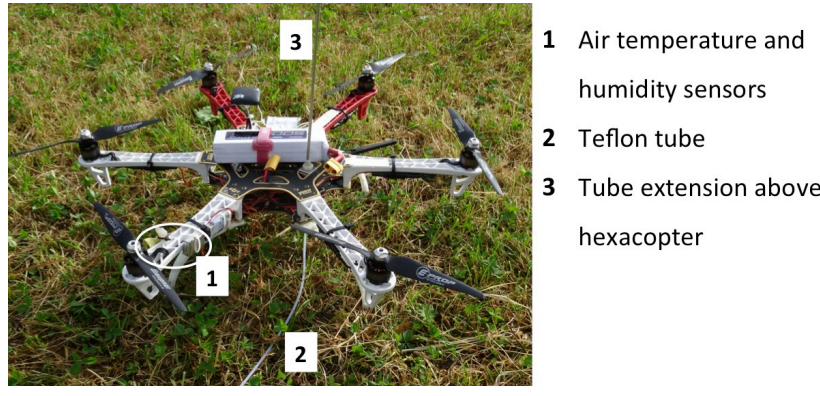

Figure 2. DJI F550 multicopter with installed sensors and tube.

dio acoustic sounding system (Sodar-RASS, Metek GmbH, Elmshorn, Germany) was installed on the east side of the area. The Sodar-RASS consists of a sodar for the wind measurement with an acoustic signal and two radar antennas for measurements of vertical profiles of air temperature (Emeis et al., 2009). The temporal resolution is $10 \mathrm{~min}$ with a range between $40 \mathrm{~m}$ and $650 \mathrm{~m}$ a.g.l. and a vertical resolution of $20 \mathrm{~m}$. In addition, vertical profiles of wind direction and speed were determined at the intercept of three simultaneously scanning Doppler wind-lidar systems (model Stream Line, Halo Photonics Ltd, Worcester, UK) as a socalled "virtual tower", in $1 \mathrm{~min}$ and $18 \mathrm{~m}$ intervals and up to approximately $800 \mathrm{~m}$ a.s.l. Methane mixing ratios were determined using a cavity ring down (CRD) spectrometer (G2508, Picarro Inc., Santa Clara, CA, USA) with an accuracy of $<0.007 \mathrm{ppm}$. The instrument was installed close to a $10 \mathrm{~m}$ tower equipped with wind speed and direction measurements (CSAT3, Campbell Scientific Ltd., Bremen, Germany, and WindMaster 3D, Gill Instruments, Lymington, Hampshire, UK) and sample air inlets at 1,5 and $10 \mathrm{~m}$ height. The three sampling lines (stainless steel, $3.2 \mathrm{~mm}$ outer diameter, $1.2 \mathrm{~mm}$ inner diameter) were flushed continuously with am- bient air and a custom-built system of solenoid valves connected one sampling line to the CRD spectrometer every $75 \mathrm{~s}$. Those measurements were complemented with UAV-based measurements that are explained in Sect. 2.2 and 2.4.

\subsection{Multicopter and its instrumentation}

The multicopter used in this study was a commercially available hexacopter DJI F550 Flame Wheel (DJI Innovations, Shenzhen, China) with dimensions of $55 \mathrm{~cm} \times 55 \mathrm{~cm} \times 30 \mathrm{~cm}$ and a frame weight of $1.3 \mathrm{~kg}$ including motors, propellers, autopilot and electronics (Fig. 2). It was equipped with a Pixhawk (3DR, Berkeley, USA) autopilot for stabilized and autonomous flights. The autopilot contains a 3-D accelerometer, gyroscope, magnetometer and barometer for position control as well as an external GPS (LEA-6 u-blox 6, u-blox, Thalwil, Switzerland) for autonomous flying. All data were logged on board, attitude angles as well as motor output at $10 \mathrm{~Hz}$, the accelerometer and gyroscope data at $50 \mathrm{~Hz}$ and GPS at $5 \mathrm{~Hz}$. Additionally, a remote receiver was installed on board for manual flying with remote control. The takeoff weight of $2 \mathrm{~kg}$ led to a flying time of approximately $10 \mathrm{~min}$ with a ground speed of $5 \mathrm{~m} \mathrm{~s}^{-1}$. In case of a communication loss of the remote control, GPS signal or low-battery status, a pre-programmed fail-safe mode took over the control and initiated the landing. The open-source software Mission Planner was used for ground control to transmit and display important flight data (e.g., height, horizontal and vertical speed, battery capacity, position) during the flights. For night flights, bright LEDs were mounted on the landing gear of the multicopter for visibility and the identification of its orientation.

This kind of UAV with a weight below $5 \mathrm{~kg}$ was chosen to fly with general flight permission from the Bavarian avi- 


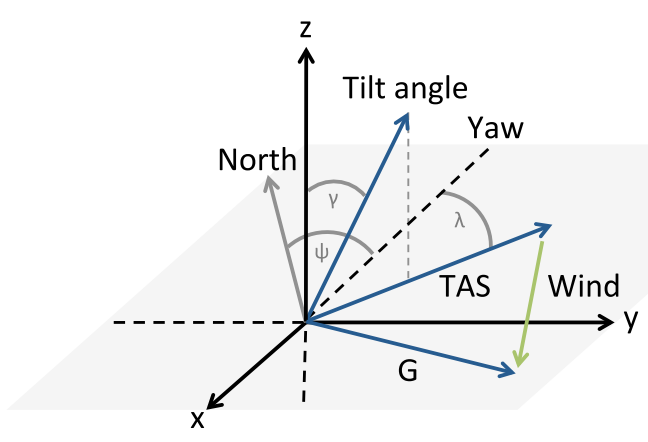

Figure 3. Relationship between the tilt angle $\gamma$ of the multicopter and the wind triangle with true air speed (TAS) vector, ground $(\mathrm{G})$ vector and wind vector. Pitch angle is in $x$ axis and roll angle in $y$ axis direction. Yaw $(\psi)$ is the viewing direction of the multicopter relative to north and the angle between TAS and yaw is $\lambda$.

ation authority, independent of area, altitude above ground and time of the day in the uncontrolled air space.

For vertical methane investigations close to the tower, a $40 \mathrm{~cm}$ long aluminum tube $(3.2 \mathrm{~mm}$ outer diameter, $1.2 \mathrm{~mm}$ inner diameter) was installed on the multicopter with the inlet about $30 \mathrm{~cm}$ above the propellers. This was attached airtight to an additional sampling line (PTFE, $3.2 \mathrm{~mm}$ outer diameter, $2 \mathrm{~mm}$ inner diameter, $70 \mathrm{~m}$ long) and connected the CRD spectrometer and the multicopter. The $70 \mathrm{~m}$ sample line was flushed at a flow rate of $350 \mathrm{sccm} \mathrm{min}^{-1}$ (calibrated for $0{ }^{\circ} \mathrm{C}$ and $1013.25 \mathrm{hPa}$ ) of which $200 \mathrm{sccm} \mathrm{min}^{-1}$ were drawn by the CRD analyzer. This resulted in a residence time of approximately $38 \mathrm{~s}$ in the tube. At $50 \mathrm{~m}$ length, the tube was an additional payload of $650 \mathrm{~g}$. Thus, the maximum ascent height was limited by the payload capacity of the multicopter.

A fast thermocouple was installed for high-time-resolution air temperature measurements. The thermocouple used was a butt-welded type K (CHROMEGA ${ }^{\circledR} /$ ALOMEGA $^{\circledR}$ CHAL003, OMEGA, Stamford, CT, USA), one wire chromium nickel alloy and the other constantan, both with a diameter of $0.08 \mathrm{~mm}$. Its measurement range was 0 to $60^{\circ} \mathrm{C}$ with an output voltage of $50 \mathrm{mV}$ per ${ }^{\circ} \mathrm{C}$. The response time was better than $1 \mathrm{~Hz}$ in calm air with an accuracy of $\pm 0.1^{\circ} \mathrm{C}$. Calibration against a reference thermometer was done in the lab. Data were logged at $10 \mathrm{~Hz}$. These data were also used together with pressure data from the autopilot for potential temperature $\left(T_{\text {pot }}\right)$ calculations to get information about the stability of the atmosphere. The used pressure sensor is a MS5611-01BA03 (AMSYS, Mainz, Germany) and is able to resolve an altitude of $10 \mathrm{~cm}$ corresponding to a precision of about $\pm 0.02 \mathrm{hPa}$.

\subsection{Wind estimation}

Multicopters move through the air by setting a tilt angle $(\gamma)$ towards the flying direction with the magnitude of tilt angle roughly proportional to speed. This angle also changes to compensate for wind variations during the flight. Therefore, without using an additional sensor for wind measurements, estimation of both horizontal wind speed and direction was possible with onboard sensors for the vehicle's attitude control by measuring the pitch (forwards and backwards), roll (left and right) and yaw (orientation to north) angles. In contrast to an aircraft, which is controlled by setting a true air speed (TAS), a multicopter flies with a given ground speed, resulting in a varying TAS.

This relationship is shown in the wind triangle (Fig. 3). The ground $(\mathrm{G})$ vector represents the speed and direction of the multicopter's movement determined by the GPS, while the TAS vector represents the actual speed and direction towards which the multicopter is heading. The deviation of $\mathrm{G}$ and TAS is caused by the wind. Assuming hovering, the tilt angle is only a result of the wind and the TAS vector is contrary to the ground vector. Consequently, in the easiest case the direction of TAS represents the horizontal wind direction and the length of the TAS vector the horizontal wind speed.

Equations applied for the wind calculation are based on Neumann and Bartholomai (2015) and explained in detail there. In this study, only vertical flights were investigated. First, the multicopter's tilt angle $\gamma$ was calculated from roll and pitch angles and then projected to the $x y$ plane, which results in the TAS vector. Then, its direction was calculated relative to the viewing direction of the multicopter (yaw angle $(\psi)$ ) and is given by the angle $\lambda$. TAS direction and simultaneous wind direction was determined by the sum of $\psi$ and $\lambda$ in case the TAS vector is on the right side of the viewing direction $\left(\left[\psi, \psi+180^{\circ}\right]\right)$. In the other case, this sum was subtracted from $360^{\circ}$ and in both cases the result has to be within 0 and $360^{\circ}$. Finally, the calculated tilt angle was inserted into a regression function to get the corresponding TAS. The length of the TAS vector represents the wind speed.

Neumann and Bartholomai (2015) used wind tunnel experiments to determine the regression function. In contrast, in our approach the length of the TAS vector was determined by relating tilt angles to specific TASs during different flight experiments. The assumption was that without wind the TAS corresponds to the flight speed measured with the GPS (GPS speed or ground speed), which has an accuracy of $0.1 \mathrm{~m} \mathrm{~s}^{-1}$. The multicopter's tilt angle was calculated by using pitch and roll angles. Their accuracy was better than $0.1^{\circ}$. Using racetrack flights, the regression function was experimentally determined during calm wind conditions with wind speeds below $1 \mathrm{~m} \mathrm{~s}^{-1}$. The track had a length of $120 \mathrm{~m}$ and had been flown six times on average for several ground speeds between 2 and $8 \mathrm{~m} \mathrm{~s}^{-1}$. While the ground speed was kept constant by the GPS $\left(< \pm 0.2 \mathrm{~m} \mathrm{~s}^{-1}\right)$, the variability of the assigned tilt angle was dependent on atmospheric conditions. To avoid an offset in the regression function the multicopter was balanced out. The resulting regression function is shown in Fig. 4 with the following Eq. (1):

$\mathrm{TAS}=0.9743 \cdot \gamma^{0.8817}$. 


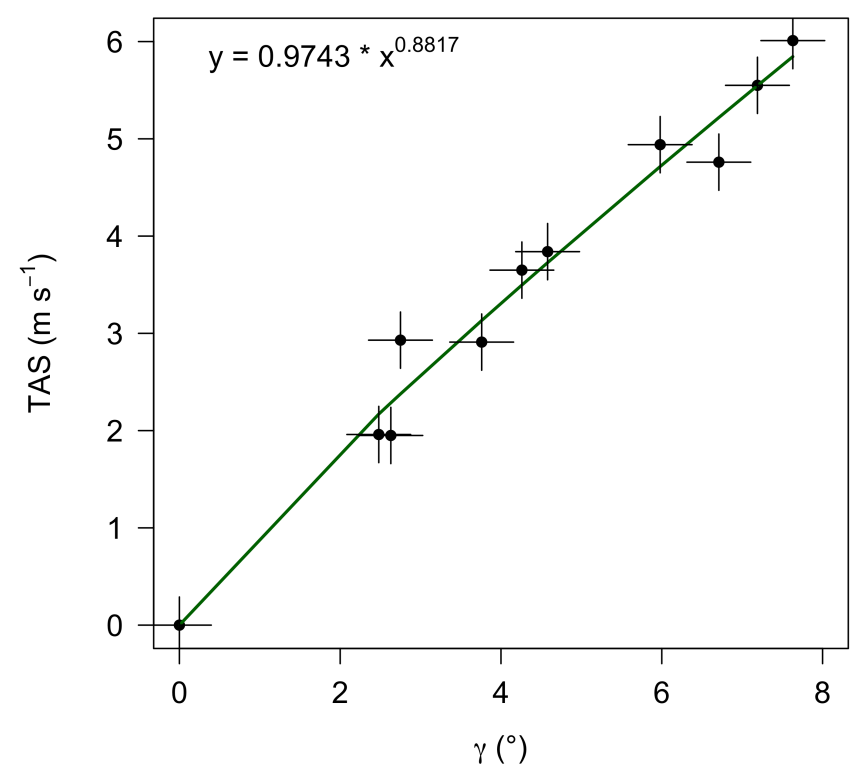

Figure 4. Regression function of relationship between true air speed (TAS) and tilt angle $(\gamma)$ experimentally determined with racetrack flights during calm wind conditions. The green line represents the fitted regression function and the error bars indicate the standard deviation of $\pm 0.4^{\circ}$ for the tilt angle and $\pm 0.3 \mathrm{~m} \mathrm{~s}^{-1}$, respectively.

The root-mean-square error (RMSE) of TAS determination was $\pm 0.3 \mathrm{~m} \mathrm{~s}^{-1}$. Based on this error for TAS, the RMSE of the tilt angle was $\pm 0.4^{\circ}$, which is similar to the one of Neumann and Bartholomai (2015). This mean error of TAS leads to a higher relative error for low wind speeds than for higher wind speeds.

With this equation, horizontal wind speed and wind direction were estimated from $1 \mathrm{~Hz}$ data and were averaged with a moving window over $10 \mathrm{~s}$ for further smoothing. To determine the inaccuracy caused by a wind speed up to $1 \mathrm{~m} \mathrm{~s}^{-1}$ during the experimental flights, the variability of the tilt angle was analyzed during hovering under calm wind conditions $\left(<1 \mathrm{~m} \mathrm{~s}^{-1}\right)$. This led to an uncertainty of $0.7 \pm 0.3^{\circ}$, corresponding to a TAS of $0.7 \pm 0.3 \mathrm{~m} \mathrm{~s}^{-1}$, which resulted in an overall accuracy of TAS estimation of $0.7 \pm 0.6 \mathrm{~m} \mathrm{~s}^{-1}$.

\subsection{Flight strategies}

To demonstrate the functionality of the wind estimation based on the attitude control sensors of the multicopter, a comparison was done to a 3-D ultrasonic anemometer (uSonic3, Metek GmbH, Elmshorn, Germany) installed at a $9 \mathrm{~m}$ tower with an accuracy of $0.1 \mathrm{~m} \mathrm{~s}^{-1}$ and $2^{\circ}$ at $5 \mathrm{~m} \mathrm{~s}^{-1}$. During windy conditions $\left(3-5 \mathrm{~m} \mathrm{~s}^{-1}\right)$ the multicopter hovered for $5 \mathrm{~min}$ close to the tower at a distance of approximately $5 \mathrm{~m}$. This horizontal distance as well as the $9 \mathrm{~m}$ height of the measurements ensured that the multicopter's downwash had an influence on neither the multicopter itself nor the anemometer. For calm wind conditions, influences of the downwash were detected up to 5-6 $\mathrm{m}$ a.g.l.

In addition, vertical wind profiles were compared to other instruments such as lidar and sodar. The EC station was used as continuous time series information close to the ground. Reaching a height of $150 \mathrm{~m}$ a.g.l. with the multicopter, the range comparable to other instruments was about $100 \mathrm{~m}$. For these flights, the vertical speed was set to $1.5 \mathrm{~m} \mathrm{~s}^{-1}$.

For methane measurements, the additional sampling line was attached to the multicopter and the spectrometer and was raised up to heights of 10,25 and $50 \mathrm{~m}$ a.g.l. A hover time of $60 \mathrm{~s}$ at each level was included to get an averaged value. The pattern was repeated every $15 \mathrm{~min}$. This led to a rotation of 5 min measurements with the multicopter and 10 min measurements at the tower at $1 \mathrm{~m}$ and $10 \mathrm{~m}$ a.g.l. For analysis, only the ascent data were used from the flights because there was no hovering during the descent. In addition, this strategy ensured that the multicopter did not mix the air before flying through. Alvarado et al. (2017) experimentally determined a distance of $40-45 \mathrm{~cm}$ above the multicopter, where the influence of the rotors to air speed decreases significantly. So, the methane mixing ratio is actually not a point measurement but valid for a volume.

While most of the flights were done above the grassland site southwest of the EC station as shown in Fig. 1, the flights including methane measurements took place close to the methane tower in the southeast of the investigation area.

Time is given in UTC, which corresponds to CEST- 2 .

\section{Results}

\subsection{Wind estimation}

Information about the accuracy of the wind estimation was determined while hovering next to an ultrasonic anemometer with a distance of about $5 \mathrm{~m}$ (Fig. 5). The multicopter-derived wind direction showed a standard deviation of $\pm 11.1^{\circ}$ and $\pm 0.7 \mathrm{~m} \mathrm{~s}^{-1}$ for wind speed within a hovering time of $5 \mathrm{~min}$. At the same time, the anemometer's wind direction varied by $\pm 10.6^{\circ}$ and wind speed by $\pm 1 \mathrm{~m} \mathrm{~s}^{-1}$. The difference between the multicopter and tower measurements averaged over $5 \mathrm{~min}$ was $7.7^{\circ}$ and $0.3 \mathrm{~m} \mathrm{~s}^{-1}$, respectively. For both time series the $10 \mathrm{~s}$ moving average was applied, resulting in a RMSE between multicopter and tower of $14.5^{\circ}$ and $0.7 \mathrm{~m} \mathrm{~s}^{-1}$, respectively. Both changes in wind speed and direction could be captured by the multicopter. The highest deviation was between 150 and $200 \mathrm{~s}$ with differences of about $30^{\circ}$ and $2 \mathrm{~m} \mathrm{~s}^{-1}$, respectively (see Fig. 5). Since the volume of the multicopter is larger compared to the measurement path of the sonic anemometer, the multicopter does not react to the small turbulent elements, the so-called eddies, and therefore cannot capture the full range of wind speed. In addition, the multicopter has inertia due to its weight. Consequently, the wind speed deviations measured by the multi- 

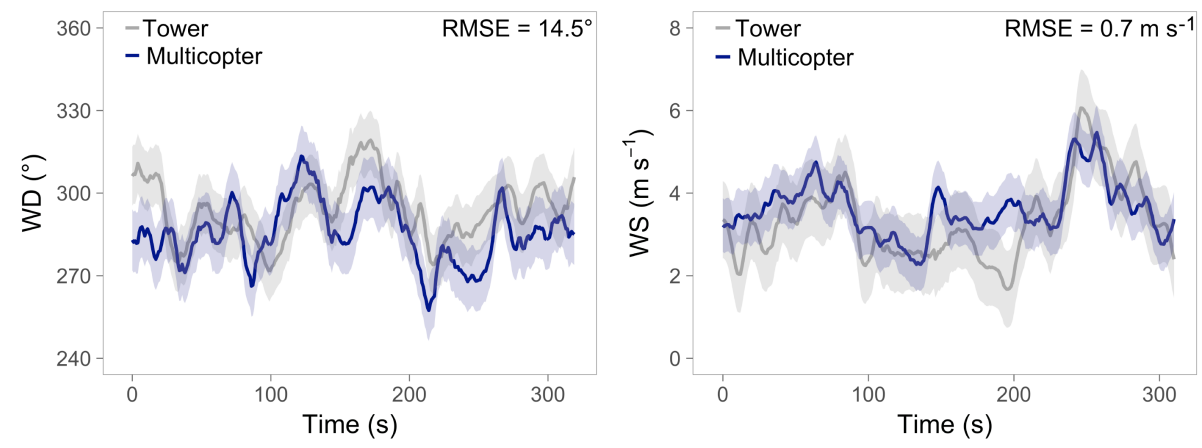

Figure 5. Wind direction (WD) and speed (WS) comparison between tower (grey) and multicopter (blue) at 9 m a.g.l. over 5 min. The colored bands around the lines represent the standard deviation of each time series.

copter should not be used as information about atmospheric turbulence.

In addition to the side-by-side measurements, wind estimation from vertical profiles was compared to lidar and sodar measurements as well as EC station data for near-ground information (Fig. 6). Both lidar and EC station data (both $1 \mathrm{~min}$ time resolution) are shown for the time around the vertical profiles of the multicopter $(\sim 4 \mathrm{~min})$. The sodar had a temporal resolution of $10 \mathrm{~min}$, so only one value was available at each height. Wind direction and speed of the UAV data were in good agreement with the recordings of the different instruments. During the flights at 09:01 and 09:31 UTC, wind direction was mainly from north to east with an increasing wind speed over time. For the first flight, spatial and temporal averages of multicopter, sodar and EC station were in agreement within $20-30^{\circ}$ and a standard deviation of about $\pm 20^{\circ}$ for wind direction. Lidar data showed higher variability than other measurements but above $100 \mathrm{~m}$ data were in the same range. Wind speed for all instruments was low with an average of about $1-1.5 \mathrm{~m} \mathrm{~s}^{-1}$ and a standard deviation of about $\pm 0.6 \mathrm{~m} \mathrm{~s}^{-1}$. For the second flight, the same was true for wind direction, but greater differences occurred for wind speed. While the multicopter and sodar recorded a mean speed of 2.6 and $2.5 \mathrm{~m} \mathrm{~s}^{-1}$, respectively, lidar and EC station had 1.7 and $1.4 \mathrm{~m} \mathrm{~s}^{-1}$, respectively. At this point it has to be highlighted that the instruments were not located at the same place (distance 100-570 $\mathrm{m}$ from multicopter; see Fig. 1) and that time resolution varied. Besides, generation of turbulence from northeasterly winds is likely at the edge of the forest, which is to the east of the investigation area. Accordingly, differences were explainable, especially at heights up to $50 \mathrm{~m}$.

\subsection{Methane and meteorological conditions}

In the night between 21 and 22 July 2015, methane measurements were made with the multicopter starting about $15 \mathrm{~min}$ after sunset (19:05 UTC) and extending over $7 \mathrm{~h}$ (Fig. 7). For comparison of tower and multicopter results, the subsequent measurements are displayed with orange points for tower data in $10 \mathrm{~m}$ and multicopter data with green ones also for $10 \mathrm{~m}$. Short-term variations in methane concentration were detected by both techniques, even with the same extent (around 22:00 UTC). There was only one major deviation shortly past midnight when the multicopter measured a value of $2.45 \mathrm{ppm}$ compared to $2.2 \mathrm{ppm}$ at the tower. This may be due to the distance of approx. $5 \mathrm{~m}$ between tower and UAV and a time difference of around $30 \mathrm{~s}$ between those measurements. Overall, the two data sets were significantly correlated with a Spearman correlation coefficient of 0.96 . Calculation of the RMSE led to $\pm 0.063 \mathrm{ppm}$. Consequently, the measurements on the moving platform were as representative as those of the stationary tower installation.

Considering the vertical methane profiles up to $50 \mathrm{~m}$ a.g.l., gradients were detectable during stable atmospheric conditions after sunset (Fig. 8). Data are shown for six flights with 1-hour intervals beginning at 19:32 UTC and ending at 00:32 UTC. According to the potential temperature profiles, a stable stratification of the atmosphere developed after sunset indicated by increasing potential temperature with height. Its difference reached 5-6 K between ground and $50 \mathrm{~m}$.

Thus, this overall stable stratification led to the reduced vertical mixing, and methane sources in the surroundings caused a concentration rise of $0.3 \mathrm{ppm}$ after sunset within $6 \mathrm{~h}$. The mean background concentration measured during this campaign was $1.9 \mathrm{ppm}$. The concentration increased at each height with time, while accumulation started from the ground. Vertical gradients were already visible right after sunset and intensified until the measurement at 22:32 UTC, weakened afterwards and then intensified again at 00:32 UTC. This variability in varying gradients was in agreement with changing meteorological conditions. Mean concentrations averaged over all measurements at each level were $2.091 \mathrm{ppm}(10 \mathrm{~m}), 2.049 \mathrm{ppm}(25 \mathrm{~m})$ and $1.976 \mathrm{ppm}$ (50 m).

According to the continuous measurements at the tower, the $\mathrm{CH}_{4}$ concentration increased close to the ground even before sunset. The strongest increase was seen at all heights between $21: 32$ and 22.32 UTC with $0.25 \mathrm{ppm}$ at $10 \mathrm{~m}, 0.15 \mathrm{ppm}$ 

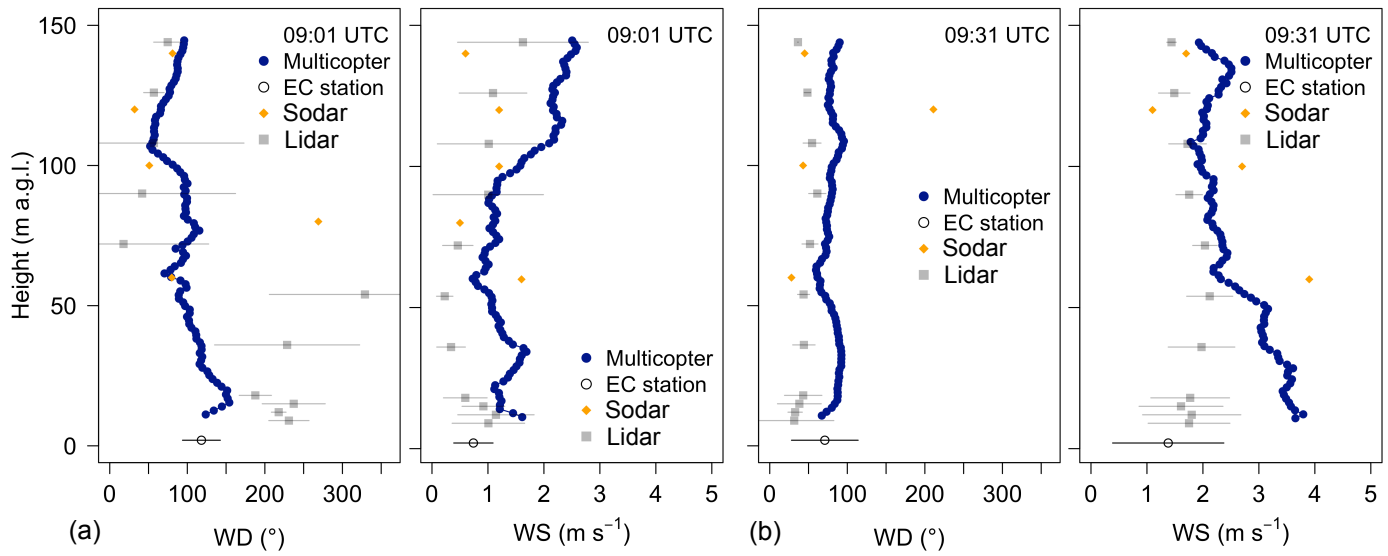

Figure 6. Wind direction and speed profiles during two different flights: 09:01 UTC (a) and 09:31 UTC (b) on 15 July 2015. The blue profiles show multicopter data, dark grey circles represent EC station data, light grey squares lidar data and orange squares sodar data. Lidar and EC station data were averaged over the time the multicopter needed for the profile. Error bars show their standard deviation.

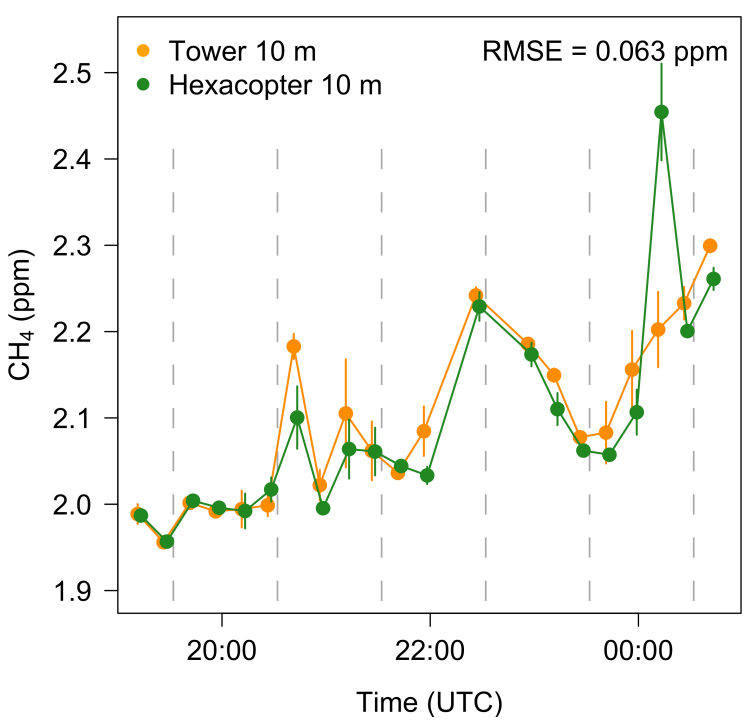

Figure 7. Methane mixing ratio measured at the tower and with the multicopter on the night between 21 and 22 July 2015. Tower data were measured just before the $10 \mathrm{~m}$ data from the multicopter. Error bars show the standard deviation for each measurement averaged over $60 \mathrm{~s}$. A standard deviation of $0.01 \mathrm{ppm}$ or less cannot be shown because the size of the data point exceeds the error bar. The dashed grey lines represent the time for which vertical profiles are shown in Figs. 8 and 9. Local time (CEST) is UTC+2.

at $25 \mathrm{~m}$ and $0.06 \mathrm{ppm}$ at $50 \mathrm{~m}$. Afterwards (23:32 UTC), concentration decreased in 10 and $25 \mathrm{~m}$ and increased in $50 \mathrm{~m}$, leading to almost the same concentration in all heights (approx. $2.07 \mathrm{ppm}$ ).

Variations in agreement with a stabilization of the NBL were observed from the vertical potential temperature profiles. The stability of the atmosphere increased, especially between 25 and $50 \mathrm{~m}$ until 22:32 UTC, while $\mathrm{CH}_{4}$ accumu- lated in the NBL. Below $25 \mathrm{~m}$, the atmosphere was slightly stable to neutral. In the following hour, a destabilization in the lowest $50 \mathrm{~m}$ of the atmosphere was detected and afterwards stable conditions developed again. This destabilization occurred simultaneously with the mixing of methane at all heights followed by a reestablished methane gradient. The results indicated a developing surface layer up to $25 \mathrm{~m}$ a.g.l. where methane accumulated, but exchange with air above was not completely inhibited likely due to the fact that turbulence was not totally suppressed.

Wind in this night was mostly from west to northwest with low speed between 1 and $2 \mathrm{~m} \mathrm{~s}^{-1}$ and up to $3 \mathrm{~m} \mathrm{~s}^{-1}$ at $50 \mathrm{~m}$ (Fig. 9), and is shown for the same times as in Fig. 8. During the first $2 \mathrm{~h}$, wind direction was roughly the same with height showing a variability of about $50^{\circ}$ (west to northwest), while wind speed was about $2-3 \mathrm{~m} \mathrm{~s}^{-1}$. Afterwards, wind speed was lower at 10 and $25 \mathrm{~m}$. Mean wind direction stayed between west and northwest at 25 and $50 \mathrm{~m}$, while at $10 \mathrm{~m}$ it changed from south (21:32 UTC) to west (22:32 UTC) and back to south and southwest (23:32 UTC). So, southern directions were accompanied by a methane decrease, lower wind speeds and higher potential temperature. In contrast to that, at 22:32 UTC wind speed was higher than $1 \mathrm{~m} \mathrm{~s}^{-1}$ and potential temperature was $4-5 \mathrm{~K}$ lower than the hour before and after. During the last flight, wind direction changed back to northwest with high variability of about $100^{\circ}$ at 10 and $25 \mathrm{~m}$, which was not seen at the second height before. This higher variability occurred mostly during low wind speeds of $1-1.5 \mathrm{~m} \mathrm{~s}^{-1}$.

\section{Discussion}

The presented results of the multicopter-based approach showed that extending measurements from towers has advantages because measurement height and location are 


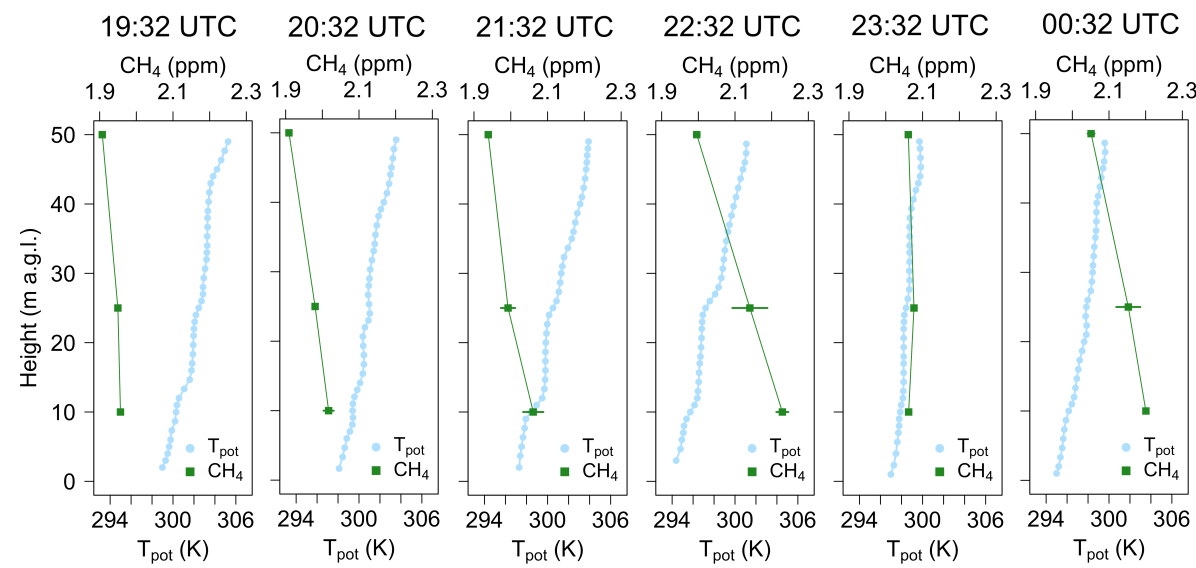

Figure 8. Vertical potential temperature $\left(T_{\text {pot }}\right)$ profiles in blue and methane concentrations in green over $6 \mathrm{~h}$ from 19:32 UTC (left) to 00:32 UTC (right) on the night of 21-22 July 2015. This corresponds to 21:32 to 02:32 CEST (UTC+2). Air temperature was measured with the thermocouple (ascent data only) and $T_{\text {pot }}$ was calculated with the onboard pressure data from the autopilot. $T_{\text {pot }}$ was averaged at hovering levels and smoothed with a moving average $(3 \mathrm{~s})$. Error bars of methane concentration show the standard deviation for each measurement averaged over $60 \mathrm{~s}$. A standard deviation of $0.01 \mathrm{ppm}$ or less cannot be shown because the size of the data point exceeds the error bar.

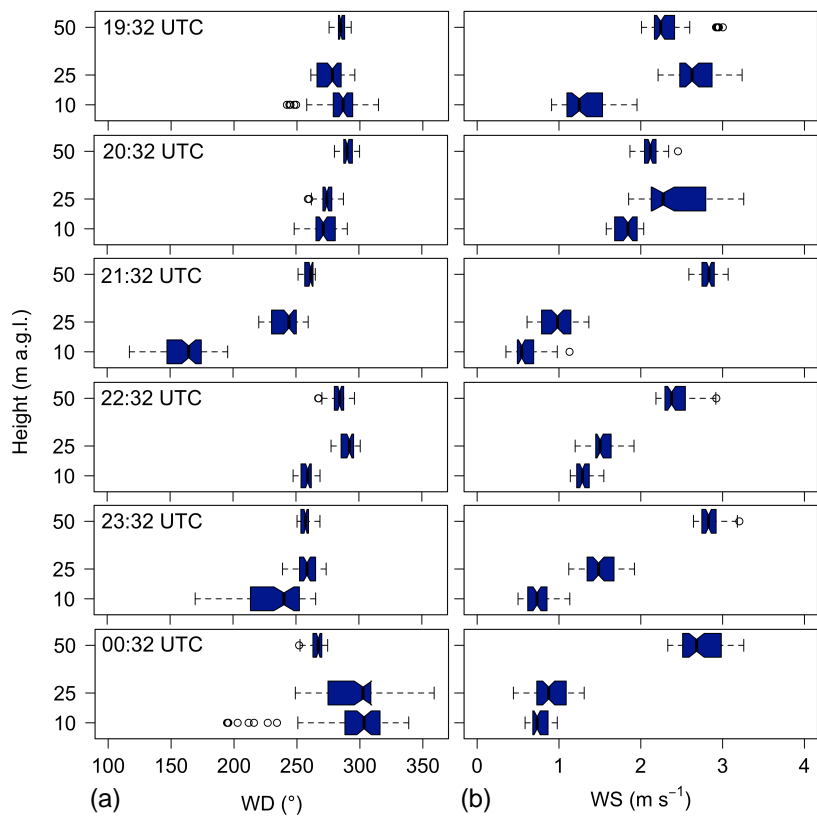

Figure 9. Variability of wind direction (a) and speed (b) during 60 s hovering at 10, 25 and $50 \mathrm{~m}$ a.g.l. for flights between 19:32 and 00:32 UTC on the night of 21 to 22 July 2015. The blue box contains $50 \%$ of the data and represents the interquartile range with the median as a black line. The dashed lines show maximum and minimum values in case those values are within the 1.5 interquartile range. Values outside this range (outliers) are represented with circles.

more flexible. Methane concentration measurements at $10 \mathrm{~m}$ height were in good agreement with those on the tower and could be conducted at different heights. Therefore, we conclude that the technique of using a tube with a multicopter could be also applicable for other inert trace gases and related research questions. In view of the good agreement of tower and UAV-based methane concentrations, plausible methane gradients were observed during stable atmospheric conditions although the multicopter does stir air with its propellers. Palomaki et al. (2017) demonstrated in an experiment that wind speed at $30 \mathrm{~cm}$ above the multicopter is $0.5 \mathrm{~m} \mathrm{~s}^{-1}$ due to spinning rotors. According to Alvarado et al. (2017) this influence is negligible at a distance of $40-45 \mathrm{~cm}$ above the multicopter.

Methane concentration increases close to the ground were found below a nocturnal inversion. Using a tethered balloon instead of a multicopter, Choularton et al. (1995) detected a concentration drop of 0.05 to $0.075 \mathrm{ppm}$ from the inversion layer to the layer above. This is in agreement with our multicopter measurements in 10 and $25 \mathrm{~m}$ a.g.l. being below $0.1 \mathrm{ppm}$ in the first half of the night while a stable stratification occurred.

The vertical range of measurements was limited by the payload capacity of the multicopter and the lateral extent of the measurements was restricted by electricity availability for the methane analyzer. Using a tethered balloon, Denmead et al. (2000) pointed out the problem that it was difficult to adapt to varying NBL heights with fixed installed sampling lines. This shortcoming can be overcome with the multicopter because hovering heights can be easily changed in the flight plan. A limitation of our setup was that the vertical range of $50 \mathrm{~m}$ is usually not enough to cover the whole NBL height. To overcome this limitation, a multicopter with a higher payload would be necessary with the ability of carrying a longer tube. Apart from that, the vertical extension of meteorological measurements to the NBL height without the tube would be beneficial to interpretation, although no methane data would be available. 
In addition, no influence of the tube on the tilt angle could be detected while hovering at 10,25 and $50 \mathrm{~m}$. A negligible influence of payload was also found by Neumann and Bartholomai (2015). At each height, the multicopter had to lift more weight, but the autopilot compensated this with the spinning speed of the propellers, which was significantly higher on the side where the tube was mounted. Therefore, it is recommended to mount the tube in the center for a better flight performance. Besides, non-gusty wind conditions are favorable to reduce the wind load on the tube.

The wind estimation carried out during hovering showed good agreement with the tower with a RMSE of $14.5^{\circ}$ and $0.7 \mathrm{~m} \mathrm{~s}^{-1}$ for wind direction and speed, respectively. These values were determined using a moving average of $10 \mathrm{~s}$. When applying a $20 \mathrm{~s}$ moving average, values of $12.5^{\circ}$ and $0.6 \mathrm{~m} \mathrm{~s}^{-1}$ are similar to those obtained by Neumann and Bartholomai (2015) for hovering. The advantage of our approach is that no wind tunnel experiments are necessary and that the experimental flights are easy to reproduce. Since the estimated errors were a result of only a 5 min flight, further experiments and comparisons would be necessary to confirm these values. Our experimentally determined relationship between TAS and the tilt angle is only valid for this hexacopter configuration and up to a speed of $6 \mathrm{~m} \mathrm{~s}^{-1}$.

Although the multicopter-based wind estimation was biased, measurements showed similar results and the results of the other instruments showed differences too. Wind speed differed up to about $1 \mathrm{~m} \mathrm{~s}^{-1}$ and direction up to $50^{\circ}$ above $50 \mathrm{~m}$. Below this height, influences of topography, land use and horizontal distance as well as averaging time were more pronounced and differences larger. Horizontal distance to the multicopter was $370 \mathrm{~m}$ for lidar and $540 \mathrm{~m}$ for sodar, while they had averaging times of 1 and $10 \mathrm{~min}$, respectively, compared to the $10 \mathrm{~s}$ moving average of the multicopter. Lothon et al. (2014), for example, found similar biased differences dependent on horizontal distance and land use during the BLLAST campaign. In addition, low wind speeds $\left(<1 \mathrm{~m} \mathrm{~s}^{-1}\right)$ lead to higher variability in wind direction, as seen for lidar data. This is because the wind is not well coupled to the mesoscale flow, which often leads to variable wind directions (Anfossi et al., 2005; Mahrt, 2011). The same is true for multicopter-based wind direction at $10 \mathrm{~m}$ during the nighttime flights, which mainly occurred during wind speeds of less than $2 \mathrm{~ms}^{-1}$. With regard to wind estimation from horizontal flights, this is especially important because flying with a specific speed requires a certain tilt angle. If this angle is significantly larger than the wind-induced angle, determination of wind contribution to the angle could be more difficult depending on the accuracy of measuring the angle.

Hovering close to the ground led to limitations in the estimation of wind from the flight control sensors. The propeller's downwash caused motion of air beneath the multicopter. These were compensated by changing the tilt angle but did not reflect actual wind conditions below a height of
5-6 m a.g.l. The effect was stronger during calm conditions because the jet of perturbed air did not advect away effectively. For the same reason, the data collected during descent were not used to estimate wind conditions because the multicopter moved through its own downwash.

Since the thermocouple was placed below a rotor, discontinuities were found while hovering; the temperature measurement is representative of the volume around the multicopter rather than a point. But this ensured a continuous flow around the sensor, which increased its response time. For analysis, temperature was averaged for hovering at each level during the methane measurements.

The combination of the wind and concentration measurements suggest that the significant methane increase between 21:32 and 22:32 UTC was caused by emissions from the dairy farms (about 150-200 dairy cows) to the west of the measurement location (about $600 \mathrm{~m}$ distance). Actually, the methane mixing ratio started to increase around 22:00 UTC (Fig. 7), when wind direction changed from more southern to predominating western directions $\left(250-300^{\circ}\right)$ with wind speeds of around $1.5 \mathrm{~m} \mathrm{~s}^{-1}$ (Fig. 9). Below $25 \mathrm{~m}$, the atmosphere was mixed according to the vertical potential temperature profile. Taking into account these conditions, dispersion of a methane plume is low. According to Dämmgen et al. (2012), an emission rate of $14.5 \mathrm{~g} \mathrm{~h}^{-1} \mathrm{cow}^{-1}$ can be assumed. This value was estimated for dairy cows in Bavaria (Germany) based on the IPCC guidelines (2006). Depending on the width of the methane plume(s) $(100-500 \mathrm{~m})$ coming from the farms, the methane concentration increase of about $0.15 \mathrm{ppm}$ in $30 \mathrm{~min}$ would lead to emissions from about 90 to 450 cows. In comparison to the actual number of dairy cows measured methane concentrations were plausible. For further investigation, an approach similar to that of Hacker et al. (2016) would be suitable to calculate emission rates by flying upwind and downwind of the farms and measuring the vertical and horizontal extent of the plume.

\section{Conclusion and outlook}

This case study demonstrated the feasibility of a multicopterbased approach to detach measurements of constituent mixing ratios and meteorological variables from fixed towers to achieve mobile and flexible investigations. Especially for difficult-to-access regions, sensible ecosystems or locations where high towers are prohibited, multicopterbased measurements could be a suitable alternative. In addition, the results highlighted the need of both meteorological and methane measurements simultaneously. Information about potential temperature is important to determine the (in)stability of the atmosphere and hence infer dispersion and mixing processes. Wind speed and direction provide information about the footprint, i.e., where the enhanced concentration originates. This is not only true for methane but is also transferable to investigations of other trace gases 
and aerosols in the air. However, to apply budget methods for ground flux estimations as discussed by Denmead et al. (2000), the vertical coverage needs to be extended, for example by utilization of a lightweight onboard methane sensor.

Also for horizontal methane investigations, a lightweight and small methane sensor on board a multicopter would be beneficial. With such a sensor it would become possible to investigate the size of the methane plumes horizontally and vertically and determine methane fluxes. Besides, the investigation of further methane sources and sinks as well as their strengths is planned in that area. To this end, horizontal wind estimation is necessary.

Data availability. Data from the ScaleX-2015 campaign are freely available for participants and upon request for third parties.

Competing interests. The authors declare that they have no conflict of interest.

Acknowledgements. This research was supported by the TERrestrial Environmental Observatory (TERENO) pre-Alpine infrastructure funded by the Helmholtz Association and the Federal Ministry of Education and Research as well as the Ground Truth Demo and Test Facilities (ACROSS) infrastructure funded by the Helmholtz Association. The corresponding author was partly supported by a scholarship of the GRAduate School of Climate and Environment (GRACE) of the Karlsruhe Institute of Technology (KIT). Their support is highly acknowledged. We also thank the Scientific Team of the ScaleX-2015 campaign for their contribution.

The article processing charges for this open-access

publication were covered by a Research

Centre of the Helmholtz Association.

Edited by: Eric C. Apel

Reviewed by: Jens Bange and two anonymous referees

\section{References}

Altstädter, B., Platis, A., Wehner, B., Scholtz, A., Wildmann, N., Hermann, M., Käthner, R., Baars, H., Bange, J., and Lampert, A.: ALADINA - an unmanned research aircraft for observing vertical and horizontal distributions of ultrafine particles within the atmospheric boundary layer, Atmos. Meas. Tech., 8, 16271639, https://doi.org/10.5194/amt-8-1627-2015, 2015.

Alvarado, M., Gonzalez, F., Fletcher, A., and Doshi, A.: Towards the Development of a Low Cost Airborne Sensing System to Monitor Dust Particles after Blasting at Open-Pit Mine Sites, Sensors, 15, 19667-19687, https://doi.org/10.3390/s150819667, 2015.

Alvarado, M., Gonzales, F., Erskine, P., Cliff, D., and Heuff, D.: A Methodology to Monitor Airborne $\mathrm{PM}_{10}$ Dust Particles
Using a Small Unmanned Aerial Vehicle, Sensors, 17, 343, https://doi.org/10.3390/s17020343, 2017.

Andrews, A. E., Kofler, J. D., Trudeau, M. E., Williams, J. C., Neff, D. H., Masarie, K. A., Chao, D. Y., Kitzis, D. R., Novelli, P. C., Zhao, C. L., Dlugokencky, E. J., Lang, P. M., Crotwell, M. J., Fischer, M. L., Parker, M. J., Lee, J. T., Baumann, D. D., Desai, A. R., Stanier, C. O., De Wekker, S. F. J., Wolfe, D. E., Munger, J. W., and Tans, P. P.: $\mathrm{CO}_{2}, \mathrm{CO}$, and $\mathrm{CH}_{4}$ measurements from tall towers in the NOAA Earth System Research Laboratory's Global Greenhouse Gas Reference Network: instrumentation, uncertainty analysis, and recommendations for future high-accuracy greenhouse gas monitoring efforts, Atmos. Meas. Tech., 7, 647687, https://doi.org/10.5194/amt-7-647-2014, 2014.

Anfossi, D., Oetti, D., Degrazia, G., and Goulart A.: An analysis of sonic anemometer observations in low wind speed conditions, Bound.-Lay. Meteorol., 114, 179-203, https://doi.org/10.1007/s10546-004-1984-4, 2005.

Bamberger, I., Stieger, J., Buchmann, N., and Eugster, W.: Spatial variability of methane: Attributing atmospheric concentrations to emissions, Environ. Pollut., 190, 65-74, https://doi.org/10.1016/j.envpol.2014.03.028, 2014.

Banta, R. M., Pichugina, Y. L., Kelley, N. D., Hardesty, R. M., and Brewer, W. A.: Wind energy meteorology: Insight into wind properties in the turbine-rotor layer of the atmosphere from highresolution Doppler lidar, B. Am. Meteorol. Soc., 94, 883-902, https://doi.org/10.1175/BAMS-D-11-00057.1, 2013.

Båserud, L., Reuder, J., Jonassen, M. O., Kral, S. T., Paskyabi, M. B., and Lothon, M.: Proof of concept for turbulence measurements with the RPAS SUMO during the BLLAST campaign, Atmos. Meas. Tech., 9, 4901-4913, https://doi.org/10.5194/amt-94901-2016, 2016.

Berman, E. S. F., Fladeland, M. L. J., Kolyer, R., and Gupta, M.: Greenhouse gas analyzer for measurements of carbon dioxide, methane, and water vapor aboard an unmanned aerial vehicle, Sensor. Actuat. B-Chem., 169, 128-135, https://doi.org/10.1016/j.snb.2012.04.036, 2012.

Beswick, K. M., Simpson, T. W., Fowler, D., Choularton, T. W., Gallagher, M. W., Hargreaves, K. J., Sutton, M. A., and Kaye, A.: Methane emissions on large scales, Atmos. Environ., 32, 32833291, https://doi.org/10.1016/S1352-2310(98)00080-6, 1998.

Chang, C.-C., Wang, J.-L., Chang, C.-Y., and Liang, M.-C.: Development of a multicopter-carried whole air sampling apparatus and its applications in environmental studies, Chemosphere, 144, 484-492, https://doi.org/10.1016/j.chemosphere.2015.08.028, 2016.

Choularton, T. W., Gallagher, M. W., Bower, K. N., Fowler, D., Zahniser, M., and Kaye, A.: Trace Gas Flux Measurements at the Landscape Scale Using Boundary-Layer Budgets, Phil. Trans. Roy. Soc. A., 351, 357-369, 1995.

Dämmgen, U., Rösemann, C., Haenel, H.-D., and Hutchings, N. J.: Enteric methane emissions from German dairy cows, Landbauforsch. Appl. Agric. Forestry Res., 1/2, 21-32, 2012.

de Boer, G., Palo, S., Argrow, B., LoDolce, G., Mack, J., Gao, R.S., Telg, H., Trussel, C., Fromm, J., Long, C. N., Bland, G., Maslanik, J., Schmid, B., and Hock, T.: The Pilatus unmanned aircraft system for lower atmospheric research, Atmos. Meas. Tech., 9, 1845-1857, https://doi.org/10.5194/amt-9-1845-2016, 2016. 
Denmead, O. T., Leuning, R., Griffith, D. W. T., Jamie, I. M., Esler, M. B., Harper, L. A., and Freney, J. R.: Verifying inventory predictions of animal methane emissions with meteorological measurements, Bound.-Lay. Meteorol., 69, 187-209, https://doi.org/10.1023/A:1002604505377, 2000.

Dlugokencky, E. J., Nisbet, E. G., Fisher, R., and Lowry, D.: Global atmospheric methane: budget, changes and dangers, Phil. Trans. R. Soc. A., 369, 2058-2072, https://doi.org/10.1098/rsta.2010.0341, 2011.

Egger, J., Bajrachaya, S., Heinrich, R., Kolb, P., Lämmlein, S., Mech, M., Reuder, J., Schäper, W., Shakya, P., Schween, J., and Wendt, H.: Diurnal winds in the Himalayan Kali Gandaki valley. Part III: Remotely piloted aircraft soundings, Mon. Weather Rev., 130, 2042-2058, 2002.

Emeis, S., Schäfer, K., and Münkel, C.: Observation of the structure of the urban boundary layer with different ceilometers and validation by RASS data, Meteorol. Z., 18, 149-154, https://doi.org/10.1127/0941-2948/2009/0365, 2009.

Forster, P., Ramaswamy, V., Artaxo, P., Berntsen, T., Betts, R., Fahey, D. W., Haywood, J., Lean, J., Lowe, D. C., Myhre, G., Nganga, J., Prinn, R., Raga, G., Schulz, M., and Van Dorland, R.: Changes in Atmospheric Constituents and in Radiative Forcing, in: Climate Change 2007: The Physical Science Basis. Contribution of Working Group I to the Fourth Assessment Report of the Intergovernmental Panel on Climate Change, edited by: Solomon, S., Qin, D., Manning, M., Chen, Z., Marquis, M., Averyt, K. B., Tignor, M., and Miller, H. L., Cambridge University Press, Cambridge, United Kingdom and New York, NY, USA, 2007

Hacker, J. M., Chen, D., Bai, M., Ewenz, C., Junkermann, W., Lieff, W., McManus, B., Neininger, B., Sun, J., Coates, T., Denmead, T., Flesch, T., McGinn, S., and Hill, J.: Using airborne technology to quantify and apportion emissions of $\mathrm{CH}_{4}$ and $\mathrm{NH}_{3}$ from feedlots, Anim. Prod. Sci., 56, 190-203, 2016.

Hammann, E., Behrendt, A., Le Mounier, F., and Wulfmeyer, V.: Temperature profiling of the atmospheric boundary layer with rotational Raman lidar during the $\operatorname{HD}(\mathrm{CP})^{2}$ Observational Prototype Experiment, Atmos. Chem. Phys., 15, 2867-2881, https://doi.org/10.5194/acp-15-2867-2015, 2015.

Holland, G. J., McGeer, T., and Youngren, H.: Autonomous aerosondes for economical atmospheric soundings anywhere on the globe, B. Am. Meteor. Soc., 73, 1987-1998, 1992.

IPCC - Intergovernmental Panel on Climate Change: 2006 IPCC guidelines for national greenhouse gas inventories, Vol. 4: Agriculture, forestry and other land use, Chapter 10, http://www.ipcc-nggip.iges.or.jp/public/2006gl/pdf/4_ Volume4/V4_10_Ch10_Livestock.pdf (last access: 21 June 2017), 2006.

Khan, A., Schaefer, D., Tao, L., Miller, D. J., Sun, K., Zondlo, M. A., Harrison, W. A., Roscoe, B., and Lary, D. J.: Low Power Greenhouse Gas Sensors for Unmanned Aerial Vehicles, Remote Sens., 4, 1355-1368, https://doi.org/10.3390/rs4051355, 2012.

Kirschke, S., Bousquet, P., Ciais, P., Saunois, M., Canadell, J. G., Dlugokencky, E. J., Bergamaschi, P., Bergmann, D., Blake, D. R., Bruhwiler, L., Cameron-Smith, P., Castaldi, S., Chevallier, F., Feng, L., Fraser, A., Heimann, M., Hodson, E. L., Houweling, S., Josse, B., Fraser, P. J., Krummel, P. B., Lamarque, J. F., Langenfelds, R. L., Le Quere, C., Naik, V., O'Doherty, S., Palmer, P. I., Pison, I., Plummer, D., Poulter, B., Prinn, R. G.,
Rigby, M., Ringeval, B., Santini, M., Schmidt, M., Shindell, D. T., Simpson, I. J., Spahni, R., Steele, L. P., Strode, S. A., Sudo, K., Szopa, S., Van Der Werf, G. R., Voulgarakis, A., Van Weele, M., Weiss, R. F., Williams, J. E., and Zeng, G.: Three decades of global methane sources and sinks, Nat. Clim. Change, 6, 813823, https://doi.org/10.1038/NGEO1955, 2013.

Konrad, T., Hill, M., Rowland, J., and Meyer J.: A small, radiocontrolled aircraft as a platform for meteorological sensors, Appl. Phys. Lab. Tech. Digest, 10, 11-19, 1970.

Korhonen, K., Giannakaki, E., Mielonen, T., Pfüller, A., Laakso, L., Vakkari, V., Baars, H., Engelmann, R., Beukes, J. P., Van Zyl, P. G., Ramandh, A., Ntsangwane, L., Josipovic, M., Tiitta, P., Fourie, G., Ngwana, I., Chiloane, K., and Komppula, M.: Atmospheric boundary layer top height in South Africa: measurements with lidar and radiosonde compared to three atmospheric models, Atmos. Chem. Phys., 14, 4263-4278, https://doi.org/10.5194/acp-14-4263-2014, 2014.

Kunstmann, H., Schneider, K., Forkel, R., and Knoche, R.: Impact analysis of climate change for an Alpine catchment using high resolution dynamic downscaling of ECHAM4 time slices, Hydrol. Earth Syst. Sci., 8, 1031-1045, https://doi.org/10.5194/hess-8-1031-2004, 2004.

Kunstmann, H., Krause, J., and Mayr, S.: Inverse distributed hydrological modelling of Alpine catchments, Hydrol. Earth Syst. Sci., 10, 395-412, https://doi.org/10.5194/hess-10-395-2006, 2006.

Lothon, M., Lohou, F., Pino, D., Couvreux, F., Pardyjak, E. R., Reuder, J., Vilà-Guerau de Arellano, J., Durand, P., Hartogensis, O., Legain, D., Augustin, P., Gioli, B., Lenschow, D. H., Faloona, I., Yagüe, C., Alexander, D. C., Angevine, W. M., Bargain, E., Barrié, J., Bazile, E., Bezombes, Y., Blay-Carreras, E., van de Boer, A., Boichard, J. L., Bourdon, A., Butet, A., Campistron, B., de Coster, O., Cuxart, J., Dabas, A., Darbieu, C., Deboudt, K., Delbarre, H., Derrien, S., Flament, P., Fourmentin, M., Garai, A., Gibert, F., Graf, A., Groebner, J., Guichard, F., Jiménez, M. A., Jonassen, M., van den Kroonenberg, A., Magliulo, V., Martin, S., Martinez, D., Mastrorillo, L., Moene, A. F., Molinos, F., Moulin, E., Pietersen, H. P., Piguet, B., Pique, E., Román-Cascón, C., Rufin-Soler, C., Saïd, F., Sastre-Marugán, M., Seity, Y., Steeneveld, G. J., Toscano, P., Traullé, O., Tzanos, D., Wacker, S., Wildmann, N., and Zaldei, A.: The BLLAST field experiment: Boundary-Layer Late Afternoon and Sunset Turbulence, Atmos. Chem. Phys., 14, 10931-10960, https://doi.org/10.5194/acp-1410931-2014, 2014.

Mahrt, L.: Surface Wind Direction Variability, J. Appl. Meteorol. Clim., 50, 144-152, https://doi.org/10.1175/2010JAMC2560.1, 2011.

Martin, S., Bange, J., and Beyrich, F.: Meteorological profiling of the lower troposphere using the research UAV "M² AV Carolo", Atmos. Meas. Tech., 4, 705-716, https://doi.org/10.5194/amt-4705-2011, 2011.

Mathieu, N., Strachan, I. B., Leclerc, M. Y., Karipot, A., and Pattey, E.: Role of low-level jets and boundary-layer properties on the NBL budget technique, Agr. Forest Meteorol., 135, 35-43, https://doi.org/10.1016/j.agrformet.2005.10.001, 2005.

Mauder, M., Cuntz, M., Drüe, C., Graf, A., Rebmann, C., Schmid, H. P., Schmidt, M., and Steinbrecher, R.: A strategy for quality and uncertainty assessment of long-term eddycovariance measurements, Agr. Forest Meteorol., 169, 122-135, https://doi.org/10.1016/j.agrformet.2012.09.006, 2013. 
McGeer, T. and Holland, G.: Small autonomous aircraft for economical oceanographic observations on a wide scale, Oceanography, 6, 129-135, 1993.

Nathan, B. J., Golston, L. M., O’Brien, A. S., Ross, K., Harrison, W. A., Tao, L., Lary, D. J., Johnson, D. R., Covington, A. N., Clark, N. N., and Zondlo, M.: Near-field characterization of methane emission variability from a compressor station using a model aircraft, Environ. Sci. Technol., 49, 7896-7903, https://doi.org/10.1021/acs.est.5b00705, 2015.

Neumann, P. P. and Bartholomai, M.: Real-time wind estimation on a micro unmanned aerial vehicle using its inertial measurement unit, Sensor Actuat. A-Phys., 235, 300-310, https://doi.org/10.1016/j.sna.2015.09.036, 2015.

Palomaki, R. T., Rose, N. T., van den Bossche, M., Sherman, T. J., and De Wekker, S. F. J.: Wind Estimation in the Lower Atmosphere Using Multirotor Aircraft, Atmos. Ocean. Tech., 34, 1183-1191, https://doi.org/10.1175/JTECH-D-16-0177.1, 2017.

Rennó, N. O. and Williams, E. R.: Quasi-lagrangian measurements in convective boundary layer plumes and their implications for the calculation of cape, Mon. Weather Rev, 123, 2733-2742, 1995.

Sasakawa, M., Shimoyama, K., Machida, T., Tsuda, N., Suto, H., Arshinov, M., Davydov, D., Fofonov, A., Krasnov, O., Saeki, T., Koyama, Y., and Maksyutov, S.: Continuous measurements of methane from a tower network over Siberia, Tellus B, 62, 403416, https://doi.org/10.1111/j.1600-0889.2010.00494.x, 2010.

Saunois, M., Jackson, R. B., Bousquet, P., Poulter, B., and Canadell, J. G.: The growing role of methane in anthropogenic climate change, Environ. Res. Lett., 11, 120207, https://doi.org/10.1088/1748-9326/11/12/120207, 2016.

Soddell, J. R., McGuffie, K., and Holland, G. J.: Intercomparison of atmospheric soundings from the aerosonde and radiosondes, J. Appl. Meteor. Climatol., 43, 1260-1269, 2004.

Spiess, T., Bange, J., Buschmann, M., and Vörsmann, P.: First application of the meteorological Mini-UAV "M2AV", Meteorol. Z., 16, 159-169, https://doi.org/10.1127/0941-2948/2007/0195, 2007.

Stieger, J., Bamberger, I., Buchmann, N., and Eugster, W.: Validation of farm-scale methane emissions using nocturnal boundary layer budgets, Atmos. Chem. Phys., 15, 14055-14069, https://doi.org/10.5194/acp-15-14055-2015, 2015.

Stull, R.: An Introduction to Boundary Layer Meteorology, 9th Edn., Dordrecht, 1988.

Velasco, E., Márquez, C., Bueno, E., Bernabé, R. M., Sánchez, A., Fentanes, O., Wöhrnschimmel, H., Cárdenas, B., Kamilla, A., Wakamatsu, S., and Molina, L. T.: Vertical distribution of ozone and VOCs in the low boundary layer of Mexico City, Atmos. Chem. Phys., 8, 3061-3079, https://doi.org/10.5194/acp-8-30612008, 2008.
Villa, T. F., Gonzalez, F., Miljievic, B., Ristovski, Z. D., and Morawska, L.: An Overview of Small Unmanned Aerial Vehicles for Air Quality Measurements: Present Applications and Future Prospectives, Sensors, 16, 1072, https://doi.org/10.3390/s16071072, 2016.

Wang, J. M., Murphy, J. G., Geddes, J. A., Winsborough, C. L., Basiliko, N., and Thomas, S. C.: Methane fluxes measured by eddy covariance and static chamber techniques at a temperate forest in central Ontario, Canada, Biogeosciences, 10, 43714382, https://doi.org/10.5194/bg-10-4371-2013, 2013.

Wolf, B., Chwala, C., Fersch, B., Garvelmann, J., Junkermann, W., Zeeman, M., Angerer, A., Adler, B., Beck, C., Brosy, C., Brugger, P., Emeis, S., Dannenmann, M., De Roo, F., DiazPines, E., Haas, E., Hagen, M., Hajnsek, I., Jacobeit, J., Jagdhuber, T., Kalthoff, N., Kiese, R., Kunstmann, H., Kosak, O., Krieg, R., Malchow, C., Mauder, M., Merz, R., Notarnicola, C., Philipp, A., Reif, W., Reineke, S., Rödiger, T., Ruehr, N., Schäfer, K., Schrön, M., Senatore, A., Shupe, H., Völksch., I., Wanninger, C., Zacharias, S., and Schmid, H. P.: The ScaleX campaign: scale-crossing land-surface and boundary layer processes in the TERENO-preAlpine observatory, B. Am. Meteor. Soc., 98, 1217-1234, https://doi.org/10.1175/BAMS-D-15$00277.1,2017$.

Worden, J., Kulawik, S., Frankenberg, C., Payne, V., Bowman, K., Cady-Peirara, K., Wecht, K., Lee, J.-E., and Noone, D.: Profiles of $\mathrm{CH}_{4}, \mathrm{HDO}, \mathrm{H}_{2} \mathrm{O}$, and $\mathrm{N}_{2} \mathrm{O}$ with improved lower tropospheric vertical resolution from Aura TES radiances, Atmos. Meas. Tech., 5, 397-411, https://doi.org/10.5194/amt-5397-2012, 2012.

Zacharias, S., Bogena, H., Samaniego, L., Mauder, M., Fuß, R., Pütz, T., Frenzel, M., Schwank, M., Baessler, C., ButterbachBahl, K., Bens, O., Borg, E., Brauer, A., Dietrich, P., Hajnsek, I., Helle, G., Kiese, R., Kunstmann, H., Klotz, S., Munch, J. C., Papen, H., Priesack, E., Schmid, H. P., Steinbrecher, R., Rosenbaum, U., Teutsch, G., and Vereecken, H.: A Network of Terrestrial Environmental Observatories in Germany, Vadose Zone J., 10, 955-973, https://doi.org/10.2136/vzj2010.0139, 2011.

Zeeman, M. J., Mauder, M., Steinbrecher, R., Heidbach, K., Eckart, E., and Schmid, H. P.: Reduced snow cover affects productivity of upland temperate grasslands, Agr. Forest Meteorol., 232, 514526, https://doi.org/10.1016/j.agrformet.2016.09.002, 2017. 